\title{
Lohner Klaudia
}

\section{Arab nevek a rendvédelmi adatbázisokban - rendszerezés, értelmezés, átírás}

\author{
Arabic names in the law enforcement databases - systematization, \\ interpretation, transcription
}

\begin{abstract}
Absztrakt
Az arab kultúra fokozott európai megjelenése hazánkat újszerü kihívásokkal állítja szembe. Ezek szerteágazó területeket ölelnek fel a bünüldözés területén. Ahhoz, hogy a migrációhoz köthető kihívásokkal meg tudjunk birkózni, elengedhetetlen, hogy a rendvédelmi szakemberek bizonyos szintig ismerjék az arab kultúrát és gondolkodást, értsék az arab nevek struktúráját, rendszerét, valamint legyenek tisztában a névátírási problémakörrel. Mindez elengedhetetlen ahhoz, hogy munkájukat a lehető legproduktívabban tudják végezni a lehető legkisebb hibázási aránnyal.
\end{abstract}

Kulcsszavak: arab nevek, azonosítás, adatbázis, migráció, rendvédelem

\begin{abstract}
The continuously growing presence of Arabic culture in Europe raises new challenges for Hungary. Diverse variety of law enforcement's expertise are contained by these challenges. In order to find a proper solution to these challenges of immigration, it is necessity for the law enforcement agencies to get familiar with the Arabic culture and their way of thinking, understand the structure of Arabic names; moreover, we have to get to know the problematic situation of the transcription of Arabic names. All these are essential for the highest level of efficiency at law enforcement agencies.
\end{abstract}

Keywords: arabic names, identify, database, migration, law enforcement

\section{Bevezetés}

Amikor arab névvel rendelkező személyek határátlépéskor vagy egy büncselekmény elkövetésekor a hatóságok látókörébe kerülnek, problémát jelenthet 
személyazonosságuk megállapítása. A Közel-Keleten zajló események hatására ${ }^{1}$ a 2015-ben tetőpontjára érö tömeges illegális migrációs hullám hazánkat is jelentős mértékben érinti. Az illegális migráció során olyan azonosítatlan személyek is érkezhetnek Európába és hazánkba, akik komoly biztonsági kockázatot jelenthetnek, így a helyzet most még inkább megköveteli az érintettek megfelelő azonosítását, illetve személyes adataik értelmezését és pontos rögzítését. ${ }^{2}$ Amennyiben az adott személy azonosítható, a hatóság tagjai sok esetben nem tudják megfelelően rögzíteni adatait - a nyelvi, kulturális, vallási különbségekből adódóan - a különböző rendvédelmi nyilvántartásokba és adatbázisokba. Ennek veszélye, hogy a már feltöltött adatok között végzett keresések, lekérdezések nem vezetnek eredményre, vagy a kapott információ nem egyértelmüen köthető az adott személyhez. A tanulmányomban tárgyaltakkal segítséget szeretnék nyújtani a rendvédelem területén dolgozóknak abban, hogy az arab személyek nevét megfelelően tudják értelmezni, rögzíteni és nyilvántartani, csökkentve az ezzel kapcsolatos biztonsági kockázatokat.

\section{Arab nevek a rendvédelemben}

Az arab nyelv tanulása során szembesültem azzal a problémával, hogy sok esetben az arab betűkkel egyféleképpen írt név (például: محمد) a latin ábécé betüivel több formában fordul elő. ${ }^{3}$ Emellett akár elemző-értékelő, határellenőrzési, felderítő vagy nyomozási tevékenységről legyen szó, az arab nevek sokszor nagyobb információértékkel bírnak, mint egy laikus szemlélő gondolná. A nemzetközi rendőri együttmüködés szempontjából is lényeges, hogy az azonosítás hibamentes, egyértelmü és egységes szemléletü legyen.

Az Országos Rendőr-főkapitányság Bűnügyi Elemző-Értékelő Főosztályán egy adatlekérdezés során olyan kérdéssel kerültek szembe az ott dolgozók, melynek nem megfelelő kezelése komoly problémát okozhatott volna: az adatlekérdezés során egy négy névtagból álló névvel rendelkező arab személyt találtak egy adatbázisban, akinek születési helye, ideje, anyja neve és a nevének nagy része is megegyezett az általuk keresett személy nevével. A személy utolsó neve tért el valamennyire a keresett személyétől. Mikor a keresési találat helyességét vizsgálták, felmerült egy olyan verzió is, miszerint az adatbázisban

1 Például: arab tavasz, szíriai polgárháború.

2 Az azonosítandó személyről az egyik elsődleges információforrás, mint természetes személyazonosító adat, az adott személy neve, így tanulmányomban ennek vizsgálatával foglalkozom. (1996. évi XX. törvény a személyazonosító jel helyébe lépő azonosítási módokról és az azonosító kódok használatáról)

3 Például: Muhamad, Muhammad, Mohamed, Mohammed; Riad, Riyad, Riyadh, Ryad, Ryadh stb. 
talált személy azonos a keresett személlyel. Ezt a lehetőséget azért kellett sorra venniük, mert a keresés feltételeinek a személyazonosító adatai alapján megfelel, csak az egyik nevében volt egy apró eltérés, amit okozhatott az adatrögzítő figyelmetlensége, vagy egy elírás is. Körültekintésüknek köszönhetően - az azonosságok ellenére -, nem tekintették azonosnak a keresett személlyel. A későbbiekben kiderült, hogy a keresett ikertestvérét jelezte találatként a rendszer.

Ez a példa két típusú problémára világít rá. Egyrészt arra, hogy Magyarországon feltehetően az emberek nagy része, így a rendőrségi dolgozók is feltételezik, hogy az arab nevek sokféleképpen szerepelhetnek egy adatbázisban. A hibázási lehetőséget az ilyen nevek rögzítésekor sokkal inkább valószínünek tartják, mint az európai ember számára könnyebben leírható és értelmezhető nevek esetében. Ezért fennáll a veszélye, hogy így is kezelik azokat a későbbiekben, és nem törekednek a precizitásra. Másrészt arra, hogy a névstruktúra ismeretének hiánya megnehezíti az értelmezést.

Az arab nevekkel kapcsolatos probléma két fö részből tevődik össze: egyrészt a nevek felépítéséböl, rendszeréböl, értelmezéséből, másrészt az arab nevek átírásából.

\section{Az arab nevek értelmezése, rendszerezése}

Az arab nevek értelmezése gondot jelenthet egy nem arab mintájú adatlap/ürlap kitöltésekor. A más kultúrkörhöz tartozó, idegen írásrendszerü nevek - az átírási nehézségeken túl (lásd a 4. Az arab nevek átírása részben) - felépítésüket, összetételüket tekintve is problémát okozhatnak. Ismeretük megkönnyítené az értelmezést, így a priorálásokat, adatbázis-kezeléseket, adatlekérdezéseket is. Ezeknek egyik speciális területe a légiutas-adatok ellenőrzése. Juhász Tamás r. alezredes, a Terrorelhárítási Információs és Bünügyi Elemző Központ Utasadat-információs és Nemzetközi Együttműködési Főosztály föosztályvezetö-helyettese a vele készített interjú során elmondta, hogy bár használnak szoftvert a nevek felismerésére, az arab nevek ismerete megkönnyítené a munkájukat, illetve hatékonyabban és biztosabban tudnák ellenőrizni a rendszer múködését. ${ }^{4}$ Azon felül, hogy az arab nevekből levonhatunk bizonyos következtetéseket egy adott személyre vonatkozóan, a rendszerezés segít abban, hogy könnyebben be tudjuk illeszteni ezeket a neveket az európai gondolkodásba, illetve alkalmassá tegyük rendszereinket arra, hogy az arab nevek rögzítésére, kezelésére is megfeleljenek. Ez könnyebbé teheti az elvégzendő munkát, legyen szó akár

4 Juhász Tamás r. alezredessel készített interjú 2018.03.26. 
egy egyszerü ürlap kitöltéséről, egy jegyzőkönyv felvételéről a rendőrségen, vagy egy adott név adatbázisba való felviteléről, adatlekérdezésről, további adatfeldolgozásról, elemzés, értékelés elkészítéséről.

\section{Az arab névadás}

Az arab nevek más nyelven írt nevektől való eltérése nem csupán az arab ábécéknek köszönhető, hanem a kulturális, vallási különbségeknek is. Az arab országokat magába foglaló régió az Atlanti-óceántól a Perzsa-öbölig terjed, Afrika északi és Ázsia délnyugati részén terül el. Kiterjedése mintegy 13 millió $\mathrm{km}^{2}$, lakóinak száma 200 millió fölött van (J. Nagy - Ferwagner, 2004, p. 7-8). Az arab 26 ország hivatalos nyelve, azonban az egész iszlám világban elterjedt ( $\mathrm{kb}$. 1,4 milliárd ember beszéli) az Atlanti óceántól Indonéziáig. Az iszlám jelenleg a második legelterjedtebb vallás a világon, ugyanakkor a híveinek a száma valamennyi más vallásénál gyorsabban növekszik (Ormos).

A névadási szabályok nem egységesek az arab világban. Külön kutatás tárgyát fogja képezni, hogy milyen névadási, illetve névátírási szabályok vannak az egyes országokban. Ennek megállapításához szükség lenne az egyes országok hivatalainak felkeresésére. Az arab névadási rendszer szabályos a maga módján, bár különböző lehet származási ország, vallás, kultúra (vidéki, törzsi, vagy városi), a formalitás szintje, sőt személyes preferencia alapján is. Általában azonban a hagyományos arab nevek öt típusát különböztetjük meg (Notzon - Nesom, 2005). Az arab névadási szokások a mai napig ezt az öt típust követik, de többnyire összetett elnevezésekkel találkozhatunk. A valódi rendszer pedig jóval bonyolultabb, mint amit ez a rendszerezés sugall. Nem minden esetben követik az elnevezési szabályokat és nem feltétlenül a szabályok szerinti nevüket használják, azonban a rendszerezés közelebb vihet minket a nevek megismeréséhez (Pálovics).

\section{Az öt személynév típus}

Iszm, az utónév

Az iszm az a név, amit az újszülött kap személyének specifikus megjelölésére a családban. Minden arab rendelkezik vele. Ez áll a legközelebb az európai keresztnévhez. Formailag lehet egyszerü (fönév, melléknév pl.: Ahmed, Mohamed, ${ }^{5}$

5 A Mohamed és Ahmed nevek a hamd vagyis hála szóból erednek. 
Aziz, ${ }^{6}$ Aysha, Szemira) vagy összetett név (Prileszky, 1987. p. 113-119). Az öszszetett nevek genitivuszos szerkezetüek. ${ }^{7}$ Ezeknek előtagja legtöbbször az abd ${ }^{8}$ főnév, utótagja pedig Allah valamelyik epitetonja, szent neve (Prileszky, 1987. p. 113-119). Istennek 99 féle tulajdonsága/neve hangzik el a Koránban', ezért 99 abd-os név van a muszlimok között. Például: (írás szerint) Abd(u) ${ }^{10}$ al-Rahman ${ }^{11}$ jelentése ${ }^{12}$ : az Irgalmas (Allah) szolgája. ${ }^{13} \mathrm{Az}$ abd-dal kezdődő nevek között vannak, amelyek nem használhatók önmagukban, vagyis az abd szónak meg kell elöznie az Allah valamelyik szent neve szerinti elnevezést (Notzon - Nesom, 2005). Ennek oka, hogy a hithü muszlimok szerint csak Allah rendelkezhet az adott 99 tulajdonsággal, ezek a nevek önmagukban csak őt illetik meg. (Például: Abd(u)Khálik/Abd(u) al-Khálik, jelentése: a Teremtő (Allah) szolgája).

\section{Lakab, a ragadványnév}

A lakab ragadványnév, külső vagy belső tulajdonságra utaló jelző, tiszteletnév vagy foglalkozási név. Egy személynek több lakab neve is lehet, amiket szituációtól függően vesznek elő (például: al-Rashid jelentése a helyes úton járó). Általában a lakab név követi az iszm-et. Például Khalid al-Rashid ibn Abd(u) al-Aziz/Abdul Aziz ${ }^{14}$, melynek jelentése Khalid, helyes úton járó Abd(u) alAziz (a Kedves (Allah) szolgája) fia (Prileszky, 1987, p. 113-119). Muhammad próféta lakab neve al-Emín, vagyis Muhammad, a becsületes, megbízható. A lakab neveket minden esetben megelözi az al határozott névelő.

Amellett, hogy az esetek jelentős részében a lakab az utónevet követi egyegy tulajdonság megjelöléseként, időnként állandósulhat. Ezekben az esetekben funkcionálhat utó- és vezetéknévként is (Pálovics).

6 Jelentése: kedves.

7 Az idegen nyelvekben olyan főnévi kifejezés, amely birtoklást vagy összetartozást fejez ki (wikiszotar.hu).

8 Jelentése: szolga.

9 أسـماء الله الحسنى ومعانيهـ (fordítás: Allah nevei és jelentései) http://iid-alraid.com/EnOfName/Allah.php (2018. 03.07.)

$10 \mathrm{Az} u$ hang a birtokos szerkezet jele, melynek ejtése elhagyható

11 Több helyen az Abd(u) al-Rahman nevet láthatjuk, azonban ez arab hangzás szerint AbduRrahman, tekintve, hogy az R betü az arab ábécé szerint az úgynevezett nap betük közé tartozik, amelyek előtt szereplő al előtagot a beszédben nem ejtjük ki.

12 Az Abd(u) al-Rahman nevet Abd(u) előtag nélkül ritkán adják egy személynek, mivel csak Allah lehet irgalmas, így használata önmagában sértésnek számít.

13 Dr. Szombathy Zoltán, az ELTE Sémi Filológiai és Arab Tanszék vezetőjével készített interjú 2018.02. 16.

$14 \mathrm{Az} \mathrm{Abd(u)} \mathrm{al-Aziz} \mathrm{nevet} \mathrm{leggyakrabban} \mathrm{Abdul} \mathrm{Aziznak} \mathrm{hallhatjuk.} \mathrm{Az} \mathrm{Abd-os} \mathrm{nevek} \mathrm{kiejtése} \mathrm{különbö-}$ ző lehet, azonban minden esetben ugyanarról a szerkezetről beszélünk, mely arabul: عبد ال Ez a kiejtésben leggyakrabban: Abdul, azonban publikációmban az írás szerint vannak feltüntetve ezek a nevek: $\operatorname{Abd}(\mathrm{u})$ al-... 
Naszab, a névlánc

Gyakran elöfordul, hogy egymás után több iszm szerepel egy arab névben, vagy $\mathrm{ibn} / \mathrm{ben} / \mathrm{bin} / \mathrm{bn}^{15}$ (jelentése: fia) vagy bint (jelentése: lánya) elválasztással. Például: Ali ibn Ahmed ibn Mohamed ${ }^{16}$. Jelentése: Ali fia Ahmednek, aki fia Mohamednek, vagyis Ali a fent már említett utónévhez leginkább hasonlító személynév, Ahmednek hívják az apját, Mohamednek pedig a nagyapját. Gyakori, hogy az ibn, bint elválasztást elhagyják és egymást követik a nevek: Ali Ahmed Mohamed, vagy például Szaddam Husszein. Utóbbi esetben tehát Hussein nem Saddam vezetékneve, hanem Szaddam, Husszein fia. ${ }^{17}$ Azt, hogy egy ilyen lánc milyen hosszú, az határozhatja meg, hogy mennyire erős a törzsi szerkezet egy arab országban. Minél erősebb, annál több apai nevet sorolnak fel a névben. Azonban figyelembe kell vennünk azt is, hogy nem mindig tudják hosszan visszavezetni a távoli ösök neveit, így ez is meghatározhatja ezek hosszúságát (Szombathy). Legjellemzőbb, hogy háromra korlátozódik a felsorolt generációk száma (Richards, 2002).

Kunja, a bizalmas név

A kunja egy bizalmas, kedveskedő, az elsőszülött fiúgyermek neve szerinti személymegjelölés. ${ }^{18}$ Előtagja az Abu (jelentése: apja) vagy Umm (jelentése: anyja), második tagja pedig a fiú iszmje, vagyis utóneve (Prileszky, 1987, p. 113-119). (Például: Abu-Musztafa, jelentése: Musztafa apja. A megjelölt személy elsőszülött fiának neve tehát Musztafa). A kunja nevek érzelmi töltettel rendelkeznek és tiszteletet fejeznek ki. Épp ezért sokszor olyanok is használják, akiknek nincs gyerekük. Gyakori szokás az is, hogy a név használatát megfordítják, vagyis például a nagyszülő úgy hívja az unokáját, ahogy őt kellene neveznie, például: Abu Abdullah-ként (jelentése: Abdullah apja) szólítja meg az unokáját, holott ő Abdullah édesapja (Szombathy).

A kunja nevek további érdekessége, hogy bizonyos neveknek van egy sztenderd kunjája, amit gyakran a név mellé is raknak, ha tiszteletteljesen akarnak beszélni az adott személlyel. Például:

15 Ha az ibn (fia) szót magánhangzóval kezdődő szó követi, az i hang leesik a kiejtésben és bn (fia) kerül a helyére. Az átírás során írják át a szót ben-re vagy bin-re ejtéskönnyítés céljából.

16 A név az európainak megfelelő vezetéknév nélkül szerepel ebben az esetben.

17 Ez állandósulhat és funkcionálhat vezetéknévként is.

18 Lánygyermek szerinti megjelölés is előfordulhat, ám ez kevésbé elterjedt. 
- Az Ali név automatikus kunjája Abu-Haszan. Ennek oka, hogy a negyedik kalifának, Alinak az elsőszülött gyermeke Haszan volt, így ez a név tulajdonképpen a vallás és hagyományok útján épült be a köztudatba és bizalmas viszonyban használható a muszlim Ali nevü személyekre.

- A Muhammad/Mohamed név automatikus kunjája Abu-Kászim. Muhammad prófétának Kászim volt az elsőszülött fia, aki gyerekként meghalt (Szombathy).

Az érzelmi töltettartalomból kifolyólag előfordul, hogy politikai, vallási vezetőket is így szólítanak (például: Jasszer Arafat ${ }^{19}$-ot Abu-Ammar-nak is szokták nevezni ${ }^{20}$ ). Annak ellenére, hogy a kunja egy bizalmas megszólítás, bizonyos esetekben, gyakori előfordulásuk miatt képződhet belőle állandó utónév is (például: Abu-Bakr, ami az első kalifa neve volt, mert fiát Bakr-nak hívták. Ez ma egy szunnita személynévként is funkcionálhat) (Szombathy). Előfordul, hogy nem az adott név sztenderd kunjáját használják, illetve nem is az elsőszülött fiúgyermekük nevéből képzik a kunja nevet, hanem egyfajta kitalált névként veszik fel azt. Gyakran fordul elö az ilyen nevek felvétele/használata szervezetekhez való csatlakozáskor (például Iszlám Állam). Általában militáns jelentésủ szavakkal párosul az „Abu” szó: például: Abu-Dzsihád (jelentése: a dzsihád apja) (Pálovics).

\section{Niszba}

A niszba eredetnév, mely általában törzset, nemzetséget, származási helyet jelöl meg, de lehet térség, altörzs vagy klán megjelölése is (Prileszky, 1987, p. 113-119) (például: Ahmed al-Ghamdi ${ }^{21}$ ) (Richards, 2002). A felsoroltak közül mindegyiknek megvan a saját niszbája. Az, hogy melyiket használják valakire, teljesen változó. ${ }^{22}$ Általában al névelővel és a valamihez tartozást kifejező -i képzővel ellátott név (például: al-Bagdadi ${ }^{23}$ ). Egyáltalán nem biztos, hogy az adott személy ott él, az sem, hogy ott született. Az eredetnév akkor válik jelentőssé, ha valaki új területen, városban telepedik le (Szombathy). Az öböl-országokban, ahol a törzsi szerkezet szinte érintetlenül létezik, nagyobb jelentősége

19 Mohammed Abd al-Raouf Arafat al-Qudwaal-Husszein (1929-2004) palesztin vezetö, politikus. 1996tól a Palesztin Autonóm Hatóság elnöke, a Palesztin Felszabadítási Szervezet vezetője és a Fatah alapítója. (https://www.biography.com/people/yasser-arafat-9187265)

20 Ammar, Arafat elsőszülött fia.

21 Jelentése: Ahmed a Ghamd törzsből.

22 Ha például a beszélgető felek ugyanabból a törzsből származnak, nem lenne értelme ugyanazt a nevet használniuk egymásra.

23 Jelentése: a bagdadi. 
van a törzsi neveknek és sokkal inkább számon tartják azokat. Itt már a jelentése is egyértelmübb, vagyis azt a törzset jelöli, ahonnan az illető származik. Ezekben a megjelölésekben szereplő „Ál” ${ }^{24}$ szó azonban nem egyenlő a határozott $\mathrm{al}^{25}$ névelővel. Az alif hangot hosszan mondjuk, az „L” hang pedig nem kapcsolódik az azt követő szóhoz (például: Ál Szaúd). Uralkodó családoknál mindig a név mögé helyezik. Egyiptomban például nagyon ritka, hogy valakinek törzsi neve van, inkább a földrajzi név a jellemző. A niszba is örökölhető, vagyis ebből is lehet családnév (Szombathy).

A női nevek esetében fontos megemlíteni, hogy a nők miután férjhez mentek megtartják első három nevüket (saját, apjuk, majd nagyapjuk iszmjét), és hozzáveszik férjük utolsó, családnév jellegü nevét. Ez a szokás sem teljesen általános, pl. Egyiptomban és Marokkóban házasság után is megmarad az eredeti teljes leánykori név (Prileszky, 1987, p. 113-119).

A legtöbb arab országban a nevek tehát utónévből, vagyis iszmböl, az apa és a nagyapa nevét tartalmazó naszabból ${ }^{26}$ és egy negyedik, niszbából vagy lakabból alakult névböl állnak, de a kunja névböl is kialakulhat idővel vezetékés utónév egyaránt.

Ahhoz, hogy egy teljes névformát áttekintsünk és értelmezzünk, vegyük példának Szaddam Husszein nevét: arab írással: صدام حسين عبدالمجيد التكريتي; latin betüs átírással: Szaddam Husszein Abd al-Majid al-Tikriti.

\section{Jelentése:}

- Szaddam: az, aki szemben áll; ${ }^{27}$

- Husszein: jó, helyes, szép (tipikus szunnita név); ${ }^{28}$

- Abd al-Majid: a Dicső (Allah) szolgálja; (Allah 99 szent nevének egyike. Kiejtése: Abd al-Mazsíd);

- al-Tikriti: tikriti (Tikrit Szaddam szülővárosa Irakban, Bagdadtól 140 km-re). Értelmezése:

- Iszm: Szaddam;

- Naszab része: Husszein (Szaddam apjának az iszmje);

- Naszab része: Abd(u) al-Majid (Husszein apjának, Szaddam nagyapjának az iszmje);

- Niszba: al-Tikriti (származási helyet jelölő név).

24 Az Ál (آل) Ahl) szóból ered, melynek jelentése: törzs.

25 Arab írásjelekkel: ال

26 A naszab nevek elsősorban a Közel-Keleten jellemzőek (a Maghreb-országokban két névből álló névstruktúrákkal találkozhatunk).

27 A صدمة (szádmá), vagyis sokk szóból ered.

28 A حسن (haszan), vagyis jó, jól szóból ered. 


\section{Egyéb elnevezési formák}

Az arab név felépülhet két (vagy több) utónév jellegü névböl is. Ezekben az esetekben valószínú például, hogy az apa, nagyapa vagy más felmenő iránti tiszteletből az adott személy nevéből képződik vezetéknév, melyet utána generációk használnak (Pálovics).

Az arabok gyakran vesznek fel neveket, ám ezek nem feltétlenül szerepelnek az irataikban. A felsorolt névfajták tehát nem törvényszerüek, tekintve, hogy nagyon rugalmasak az arab elnevezési formák bizonyos területeken, illetve nem feltétlenül az irataikban szereplő név a meghatározó és mindennapokban használt (Pálovics).

A probléma összetettsége miatt külön publikáció tárgyát képezné az arab nevek más elnevezési szabályokkal (például orosz) való keveredésének vizsgálata.

\section{Nevekből levonható következtetések}

Az öt személynévtípus megismerésével már levonhatunk olyan következtetéseket, amelyek segítenek a nevek értelmezésében. A névrögzítés egyik útja az ürlapok, adatlapok kitöltése. Érthető módon saját gondolkodásunkba szeretnénk beilleszteni ezeket a neveket akkor is, amikor valakinek egy szabvány szerinti adatlapra visszük fel a nevét. Az első, amit tudnunk kell, hogy melyik egy arab személy vezeték- és utóneve. Amint azt fent láthattuk, alapvetően az iszm felel meg az európai utónévnek. Vezetéknév pedig képződhet lényegében bármely személynév típusból: iszmböl, kunjából, niszbából és lakabból (Pálovics). Az arab nevek jelentős része azonban nem két névből áll. A köztes nevek az arab útlevelekben többnyire az utónévnél vannak feltüntetve (lásd 1. ábra: líbiai magánútlevél), illetve például Egyiptomban az egész nevet egy sorba teljes névhez (full name) írják (lásd: 2. ábra: egyiptomi magánútlevél). ${ }^{29}$

Fontos megjegyezni, hogy mikor ezeket a neveket magyar mintára megfordítjuk, hogy a vezetéknév kerüljön előre, az elsőként feltüntetett név pedig hátra, akkor a birtokos szerkezet miatt megváltozhat a név jelentése. Ezért speciális megfordításra van szükség: lásd a 3., az Arab utónév és vezetéknév átírt sorrendje címü ábrán.

A kunja nevek ismerete segítheti a következtetések levonását, ám ez is nagy körültekintést igényel. Ha például helyszíni információgyüjtés során keresünk egy személyt - és tisztában vagyunk az irataiban szereplő nevével -, előfordul-

29 Az ábrán szereplő utónevek, a fenti besorolás szerint, a naszab névhez taroznak, vagyis az apa és nagyapa nevét is tartalmazzák. 
hat, hogy ismerősei a kunja nevén ismerik. Itt akkor van egyszerübb dolgunk, ha az adott személy a kunja nevet valóban az elsőszülött fia után kapta, illetve ha a nevéhez tartozó sztenderd kunja nevén ismerik. Ha azonban ez egy felvett kunja név, az ezzel kapcsolatos ismeretek nem vezethetnek eredményre.

Az arab történelmet és kultúrát ismerve a nevekböl következtetni lehet arra is, hogy mely vallási irányzathoz tartozhat az adott személy. A keresztény arabok nevei származhatnak a Bibliából. Az egyik példa Butros, ami a Péter név arab változata. Ezek a nevek ugyanazt a felépítést követik, mint más arab nevek. A közelmúltban az iszmek listájára kerültek nyugati nevek, melyeket jellemzően a keresztény arabok, illetve a nyugati befolyású területeken élők használhatnak, például: Bejrútban, Ammanban vagy Tuniszban. Ilyen név lehet például: Emile Safwad Youssef (Netzon - Nesom, 2005).

A síiták kerülik a történelmi szunnita nevek használatát, mint például: AbuBakr, Muhammad/Mohamed, Omán vagy Oszmán. Tipikus síita név például Husszein, Ali, Haszan. Azokban a közösségekben, ahol a szunnita vahabizmus fanatikus ideológiája dominál, fokozottan kerülik a síita nevek használatát (Pálovics). A keresztnevek jelentőségének jó példája, hogy a 2006-os iraki polgárháborús helyzetben Bagdadban jellemzően a síiták és szunniták a keresztnevük alapján választották ki ellenségüket. Ez volt az egyetlen, könnyen felismerhető vallási megkülönböztető jelző (Ghosh, 2006).

A nevek hosszából, felépítéséből következtethetünk arra, hogy melyik országból származik az adott személy. Mint azt fent említettem, a Maghreb-országokban (Marokkóban, Algériában, Tunéziában és Nyugat-Szaharában) a két névből álló elnevezési formák jellemzők, míg a Közel-Keleten a naszabot követi a vezetéknév.

Abból, hogy valaki Allah 99 szent neve valamelyikét az abd szó nélkül adja gyermekének, következtethetünk arra, hogy az illető nem erősen vallásos. ${ }^{30}$ Legyen szó akár síita, akár szunnita vallási irányzathoz tartozóról.

\section{Az arab nevek átírása}

A magyar helyesírás szabályai tartalmazzák a nem latin betüs írású nyelvekből átvett tulajdonnevek és közszavak átírási szabályait. E szerint az átírás elvei a következők:

30 Mint azt már említettem, a 99 név közül vannak olyanok, amelyek állhatnak önmagukban, illetve vannak, amelyek nem. Ez nem mindegyik szent névre igaz, bár valószínüsíthető, hogy a fanatikus vallási irányzatok követői ezeket nem használják abd nélkül. 
A szépirodalmi mủvekben, a sajtóban, a közoktatást szolgáló kiadványokban a nem latin betüs írású nyelvekből átvett tulajdonneveket és közszavakat a magyar ábécé betüivel, lehetőleg egyenesen a forrásnyelvből (tehát más nyelv közvetítése nélkül) írjuk át. Átíráskor az idegen hangsort (pl. a kínai esetében) vagy az idegen betü- és hangsort együtt figyelembe véve (pl. az orosz, az arab, a görög esetében) nyelvenként szabályozott módon helyettesítjük magyar hangokkal, illetve az ezeknek megfelelő magyar betükkel. A magyaros átírás alkalmazása a forrásnyelvvel kapcsolatban kialakult közgyakorlattól is függ. Ha egy tulajdonnév vagy közszó nem szabályosan átírt alakban honosodott meg, hagyományos formájában használjuk.

A magyaros átírású tulajdonneveket és közszavakat a bennük szereplő betük magyar hangértéke szerint kell olvasni, például: Hérakleitosz, Marrákes, hidzsra $[\ldots] .{ }^{31}$

Az arab világban funkcionális kétnyelvüség (diglosszia) van, ami azt jelenti, hogy bár írásban egységesen, illetve bizonyos esetekben (például hírolvasáskor) is ugyanazt a nyelvet használják, a mindennapi életben mindig a helyi dialektusokban beszélnek, melyek nagyon különbözőek is lehetnek egymástól. (Ormos) James Richards a Middle Eastern Naming Conventions címü tanulmányában külön csoportként említi a klasszikus írásos arab nyelvet, amiben a Korán ${ }^{32}$ íródott. A Modern Sztenderd Arab nyelvet (továbbiakban: MSA) pedig a klasszikus Koránban írott nyelv modern verziójának tekinti. Függetlenül attól, hogy milyen dialektust beszél, minden arabul beszélő személy megérti és tudja olvasni az MSA-t (Richards, 2002).

Az arab ábécé 28 betüből áll. Az alap íráskép nem tartalmaz rövid magánhangzókat, azokat egyfajta segítségként, a betük fölé, illetve alá írják (lehet fatha, damma vagy kaszra ${ }^{33}$. Ezeket a mindennapi írásban általában elhagyják, ami az európai nyelvekre való átíráskor komoly problémákat, tévesztéseket okozhat. Az olvasó az adott mássalhangzókból, a szó ismeretében tudja kiolvasni a leírtakat (Richards, 2002). Jobbról balra írnak, ezért a könyveket, füzeteket is hátulról lapozzák.

Az arab nyelvben különbséget teszünk a betük között abban a tekintetben, hogy hasonulnak-e az eléjük kerülő határozott névelöhöz $(\mathrm{al}=\mathrm{l})$. Ez alapján megkülönböztetünk Nap és Hold betüket. Előbbihez hasonul a határozott né-

31 A magyar helyesírás szabályai. Budapest, Akadémiai Kiadó, 12. kiadás, 2015. Érvényes: 2015. szeptember 1-jétől. http://helyesiras.mta.hu/helyesiras/default/akh12 (2018.04.08.)

32 Korán: a muszlimok szent könyve, amely az isteni útmutatás forrását jelenti minden muszlim számára. Muhammad próféta kinyilatkoztatása, amely biztosítja a muszlimok számára a mindenkori hit- és értékrendszert. (What is the Quran? https:/www.whyislam.org/submission/the-holy-quran/what-is-thequran/ 2018.03.22.)

33 Vagyis a, u vagy i hang. 
velö, utóbbihoz nem. ${ }^{34} \mathrm{Az}$ al névelő gyakran része az arab tulajdonneveknek, így a neveknek is. A névelöt a magyarra történő átírás során mindig kötőjellel kapcsoljuk az azt követő szóhoz és mindig kis betủvel írjuk. ${ }^{35}$ Számos személynév esetében is előfordul névelö, melyek a fenti szabályok szerint hasonulnak, illetve kötöjellel kapcsolódnak a következö névelemhez, viszont egybeíródnak az azt megelőzővel (pl. Abdal-, Abdel-). ${ }^{36}$ Mivel viszont az alláh (elláh), addín (eddín) végü neveket mindig egybeírjuk a megelőző névelemmel, az Abdalláh (Abdelláh) ${ }^{37}$ névnél ez a kötőjel elmarad. A már említett Umm- és Abu- névelemet, valamint ennek névelővel kiegészült, és így hasonulni képes Abul- alakját mindig nagybetűvel kezdjük, és kötőjellel kapcsoljuk a név további részéhez. Láthattuk, hogy gyakori névelem az ibn, ben, bin. ${ }^{38}$ Ezeket mindig külön írjuk, és ha nem névkezdő helyzetben állnak, mindig kisbetüsek.

Bizonyos szavakat nem szabályszerúen, hanem hagyományos alakjukban kell átírni: Algír, Allah, Bejrút, Casablanca, Damaszkusz, Jasszer Arafat, Kába, Kadhafi, Kairó, Mohamed (a próféta neveként, illetve a modern névanyagban; a klasszikusban: Muhammad), Nasszer, sejk, Szadat, Szuez, Tripoli, Tunisz (Laczkó - Mártonfi, 2006, p. 267-268).

Bár hazánkban le vannak fektetve az átírás szabályai, a névátírási rendszer alkalmazása nem egységes. Ezért is fordul elö, hogy egy arab név több formában is szerepelhet egyes adatbázisokban, nyilvántartásokban. Például az Osama név Ussama, Oszama vagy Oszámáként is. A médiából való átírás is komoly torzulásokat okozhat. Kadhafi nevét például rengeteg formában találhatjuk meg az interneten mind az angol, mind a magyar weboldalakon (Péli, 2011). Ennek oka, hogy a magyar média sok esetben a külföldi sajtóból merít, és nem a saját átírási rendszerünket használjuk (Pálovics).

Az arab betűkről latin betükre történő átírásnál problémát jelent, hogy különböző országokban különféleképpen írják át a betüket. Létezik azonban egy egységes átírási rendszer, melyet az Egyesült Nemzetek Szervezete vezetett be. Az arab országokban általános, hogy francia vagy angol átírás szerint írják át az arab szavakat, így a neveket is. Angol fonetika alkalmazása jellemző Egyiptomban, Szudánban, a Perzsa-öböl mentén és a közel-keleti országokban, mint Szaúd-Arábiában, Irakban vagy Izraelben. Francia átírással pedig Észak-Afrikában és a Maghreb-országokban találkozhatunk. Spanyolországban például -

34 A hasonulás azt jelenti, hogy az 1 hangot nem ejtjük, az első magánhangzót pedig megduplázzuk a kiejtésben.

35 Egy másik ejtési változat szerint el-nek mondjuk.

36 Laczkó Krisztina, Mártonfi Attila Helyesírás címủ kötetében szereplő Abdal-, Abdel- kifejezések megfelelnek az általam fent írás szerinti Abd(u) al- ...-nak írt, gyakran Abdul-nak ejtett szavaknak.

37 Jelentése: Allah szolgája, melyet gyakran hallhatunk Abdullah-nak.

38 Mindhárom szó jelentése fia. Arabul írásuk lehet: بن vagy ابن 
akárcsak hazánkban - az egységes átírás nem felelt meg a spanyol kiejtésnek, ezért saját átírási rendszert hoztak létre. Marokkóban és Nyugat-Szaharában második nyelvként sokan a spanyolt használják, illetve jelentős számú arab bevándorló él Spanyolországban. Ennek köszönhetően sok arab szót vettek át a spanyolok, így a két ország közelsége miatt könnyebben fel tudták állítani a saját átírási rendszerüket. ${ }^{39}$ Így tehát azokban az esetekben, amikor egy arab nevü személy okmányaiban latin betükkel is szerepeltetik a nevet, nem lennének egységesíthetők azok a nevek, melyeket az arab ábécé betüivel ugyanúgy írunk. A különbözö átírási rendszerek miatt például, abban az esetben, ha egy arab nevü személy nevének rögzítése elöször spanyol átírási szabályok szerint történik, mikor hazánkba érkezik, a neve abban a formában fog bekerülni valamely nyilvántartásunkba, ahogy azt a spanyol rendszer szerint rögzítették. Jelen publikáció terjedelmi korlátai nem teszik lehetővé a különböző országok névátírási, névbejegyzési szabályainak vizsgálatát és összehasonlítását. Ez azonban elengedhetetlen ahhoz, hogy egységes szabályok szerint müködjön nemzetközi szinten is az arab személyek nevének rögzítése. Ezzel könnyebbé és hatékonyabbá tehetjük az azonosítást, amely segíti a nemzetbiztonsági kockázatot jelentő személyek kiszürését. Első lépésként az Európai Határ- és Partvédelmi Ügynökség (FRONTEX) ${ }^{40}$ a Bünügyi Rendőrség Nemzetközi Szervezete (INTERPOL), ${ }^{41}$ az Európai Rendőrségi Hivatal (EUROPOL) ${ }^{42}$ felkeresése lenne indokolt, illetve minden olyan rendvédelemhez kötődő szervezeté, amely nemzetközi szinten kapcsolatba kerül a a nemzetközi (föleg illegális) migrációval. Ezzel párhuzamosan a különböző európai, illetve arab országok névátírási szabályainak megismerése is elengedhetetlen.

A fent ismertetett névátírási nehézségek áthidalásának léteznek informatikai-matematikai megoldásai, ám ezek (például fonetika, szinonimakezelés, matematikai hasonlóságvizsgálatok $)^{43}$ önmagukban nem feltétlenül elégségesek a probléma megoldásához. Szükség van olyan szakemberekre, akik kontrollálják ezeket a rendszereket, esetenként ellenőrzik azok eredményeit, valószínüség esetén pedig megvizsgálják a produktumokat. Azokban az esetekben pedig, ahol nincs lehetőség (erőforrás vagy megoldás hiánya miatt) szoftverek alkalmazására, a szakértők, tolmácsok, orientalisztikai szakértők, arab nyelvet ismerők munkája még kiemeltebb szerepet töltene be.

\footnotetext{
39 fundéBBVA - Sistemas de transcripción Guía de aplicación Versión 1.2. 24-8-2015 (jelentése: BBVA Alapítvány - Átírási rendszer alkalmazási útmutatója 1.2-es verzió). https://www.fundeu.es/wp-content/ uploads/2014/04/TranscripcionesGuiaFundeu.pdf (2018. 04. 09.)

40 Frontières extérieures.

41 The International Criminal Police Organization.

42 The European Union Agency for Law Enforcement Cooperation.

43 Mérnökinformatikussal készített interjú a probléma informatikai megoldásairól 2018.03.21.
} 


\section{Befejezés}

Magyarország és Európa a migrációs válságban új kihívásokkal szembesült. A 2015 előtt még mérsékeltnek tekintett problémák mára komolyabb nemzetbiztonsági kockázatot jelentenek. Hazánk védelmi szerveinek feladata nem csak országunk, de a schengeni övezet bizonyos határszakaszának védelme is. A bünüldözés speciális, mégis számos részterületet magába foglaló kérdése a nemzetközi migráció és az azzal összefüggő kockázatok mérséklése. Ilyen kihívás az arab nevek megismerése, rögzítése és kezelése is. Mint azt láthattuk, egy nehéz, bonyolult és globális szintủ problémáról van szó, amelyre a közeljövőben megoldást kell találnunk, és a nemzetközi szinten való együttmüködést még szorosabbra kell füznünk, ha produktív végeredményt szeretnénk.

A nemzetközi szintü egységesítés - az arab nevek kezelése, rögzítése tekintetében - még várat magára, de a fentiek megértése és alkalmazása addig is segítheti a hazánkban müködő rendvédelmi szervek munkáját. Ennek a megismerési folyamatnak a része az arab történelem, szokások, kultúra ismerete, az arab személyekkel folytatott kommunikáció. E speciális területen oktatásra lenne szükség, mely a felsoroltak mellett kiterjedne az arab nevekre is. Ha a rendvédelem területén dolgozók átfogó képet kapnak az arab nevek struktúrájáról, felépítéséről, rendszeréről az adatok felvétele, rögzítése sikeresebbé, a munka pedig hatékonyabbá válik. Ehhez a minőségi javuláshoz szükséges egy olyan kétirányú kommunikáció, mely során a különböző szakterületek képviselői ismertetnék az arab kultúrával foglalkozó szakértőkkel a fő problémákat, így szoros együttmüködés keretében kellene megtalálni a legideálisabb megoldást. E terület oktatása során szükségszerü a szervek közötti prioritás felállítása, ám lényeges eleme, hogy a végrehajtóitól a vezetôi szintig eljussanak a szükséges információk.

\section{Felhasznált irodalom}

Beth Notzon and Gayle Nesom: Arabic Naming System 2005. https://www.councilscienceeditors.org/wp-content/uploads/v28n1p020-021.pdf

European Council - Council of the European Union: Public Register of Authentic travel and identity Documents Online. http://www.consilium.europa.eu/prado/en/search-by-document-country.html

Ghosh, B. (2006): Where your name can be a Death Sentence. http://content.time.com/time/ world/article/0,8599,1212291,00.html 
J. Nagy, L. - Ferwagner, P. Á. (2004): Az arab országok története. Szeged: JATE Press

Laczkó, K. - Mártonfi, A. (2006): Helyesírás. Budapest: Osiris Kiadó

Magyar Tudományos Akadémia (2015): A magyar helyesirás szabályai. Budapest: Akadémiai Kiadó

Ormos István: Az arab nyelv és irás. In: Zólyomi, G. (szerk): Ókori és keleti nyelvek és írások.

Péli, P. (2011): Kadafi, Qaddafi, vagy Gaddafy? A libiai elnök 112 neve. https:/www.nyest.hu/ hirek/kadafi-qaddafi-vagy-gaddafy-a-libiai-elnok-112-neve

Prileszky, Cs. (1987): A névadás jellegzetességei az arab nyelvben. Intézeti Szemle 15. 113-119.

Richards, J. (2002): Know Your Customer - Naming Conventions for Arabic, Russian, Chinese,

Vietnamese, Western African \& Hispanic Cultures. American Tax payer Identification Numbers. https://www.bankersonline.com/sites/default/files/tools/namingconventions_0.pdf

Sistemas de transcripción Guía de aplicación Versión 1.2. 24-8-2015 (fundé BBVA) (jelentése: BBVA Alapítvány - Átírási rendszer alkalmazási útmutatója 1.2-es verzió) https://www.fundeu.es/wp-content/uploads/2014/04/TranscripcionesGuiaFundeu.pdf

أسماء الله الحسنى ومعانيها (fordítás: Allah nevei és jelentései) http://iid-alraid.com/EnOfName/Allah.php

1996. évi XX. törvény a személyazonosító jel helyébe lépő azonosítási módokról és az azonosító kódok használatáról.

Juhász Tamás r. alezredessel készített interjú 2018.március 26-án.

Mérnökinformatikussal készített interjú a probléma informatikai megoldásairól 2018. március. 21-én.

Pálovics Ede orientalisztikai szakértővel készített interjú 2018. április 1-jén.

Szombathy Zoltánnal, az Orientalisztikai Intézet intézetigazgatójával, az Eötvös Loránd Tudományegyetem Filológiai és Arab Tanszék vezetőjével készített interjú 2018. február. 16-án. 


\section{Mellékletek}

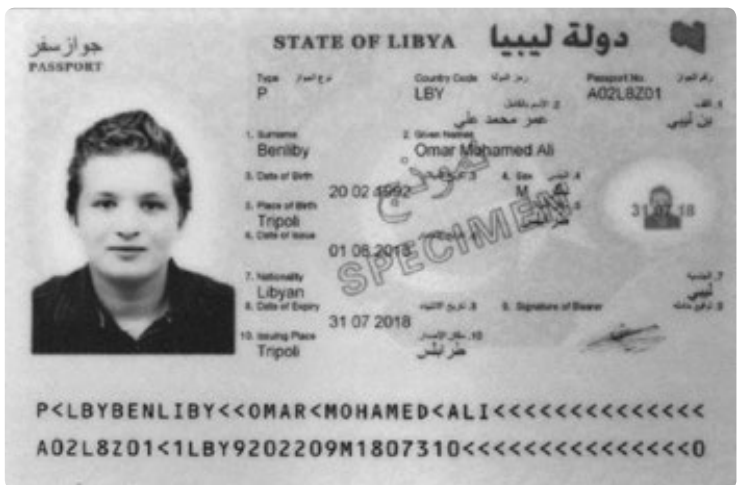

1. ábra: Líbiai magánútlevél

(http://www.consilium.europa.eu/prado/en/search-by-document-country.html

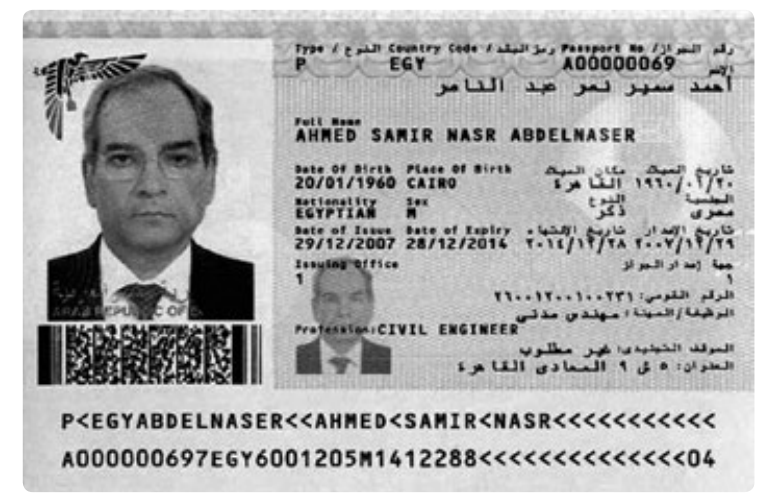

2. ábra: Egyiptomi magánútlevél

(http://www.consilium.europa.eu/prado/en/search-by-document-country.html)

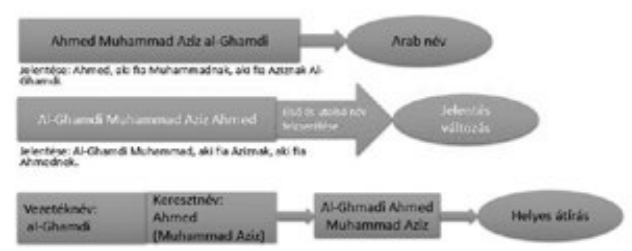

3. ábra: Arab utónév és vezetéknév átírt sorrendje (Készítette a szerző) 